\title{
ANALISIS STRATEGI PEMASARAN PADA GERAI TRANSMART CARREFOUR PABELAN (Study Kasus Pada Konsumen Transmart Carrefour Pabelan)
}

\author{
Fiki Meliyanawati, Supawi Pawenang, Solichul Hadi AB
}

Fakultas Ekonomi Manjemen Universitas Islam Batik surakarta

Email : fikimeliyanawati11@gmail.com

\begin{abstract}
The purpose of this study was to analyze the marketing strategy at the Prefan Carrefour Transmart outlet. This type of research uses quantitative research. The population of this study is consumers of Carrefour Pabelan Trnasmart outlets, samples in the study were 100 people sampling techniques using random sampling methods, data analysis techniques used in this study using multiple linear regression. $F$ test results indicate that the location, promotion and quality of service simultaneously and significantly influence the purchase decision on the Carrefour Pabelan Transmart Outlet. $T$ test results showed that the location had a positive and significant effect on purchasing decisions at the Pabelan Carrefour Transmart Outlet, promotion had a positive and significant effect on purchasing decisions at the Pabelan Transmart Carrefour Outlet, service quality had a positive and significant effect on purchasing decisions at the Prefan Carrefour Transmart Outlet. Dermination coefficient shows the location, promotion and service quality has an influence of $57.5 \%$ on the purchase decision variable in the Pabelan Carrefour Transmart Outlet.
\end{abstract}

Keywords: Location, Promotion, Service Quality, Purchasing Decisions

\section{PENDAHULUAN}

Perusahaan pada umumnya hidup dalam lingkungan yang berubah dengan cepat, dinamis dan cenderung rumit. Harus mampu bersaing dalam menunjukan keunggulan akan produk atau jasa yang dijual dibanding komptitornya. Jika suatu perusahaan ritel mampu mendapatkan konsumen dengan jumlah banyak, langkah selanjutnya yang dilakukan adalah bagaimana caranya konsumen tersebut bisa menjadi pelanggan tetap dan mempertahankan loyalitas konsumen untuk terus berbelanja di perusahaan ritel tersebut. Dalam praktik bisnis ritel saat ini tidak menutup kemungkinan banyak pengecer kecil yang membeli kebutuhan sehari-hari digerai ritel besar, mengingat perbedaan harga yang sering muncul waktu promosi tertentu, serta lokasi dan kualitas pelayanannya yang menjadi pertimbangan saat membeli atau berbelanja diperitel besar (Yola dan Budianto, 2013).

Brata, Baruna Hadi, dkk (2017) menyatakan bahwa lokasi merupakan salah satu faktor lain untuk melakukan sebuah promosi, karena dengan strategisnya lokasi bisa menambah nilai jual dalam membangun sebuah perusahaan serta bisa menambah daya tarik konsumen. Didalam konsep pemasaran telah dinyatakan bahwa perusahaan atau produsen tidak hanya membuat barang, tidak pula asal melancarkan prmosi akan tetapi juga harus diimbangi dengan sebuah pelayanan yang sesuai dan pelanggan puas. (Heryanto, 2015) Menyatakan promosi merupakan salah satu strategi pemasaran yang sangat penting seperti halnya perusahaan memberikan discount, buy 1 get 1 , atau bahkan promosi 
lainnya yang menarik konsumen agar selalu menggunakan produk atau jasa yang telah disediakan oleh perusahaan ritel.

Selanjutnya kualitas pelayanan merupakan faktor atau strategi pemasaran yang dianggap mampu mempengaruhi keputusan pebelian. kualitas pelayanan adalah cara untuk mencari hati para konsumen karena dengan pelayanan yang baik konsumen akan merasa sangat puas dan senang karena produk dan jasa yang mereka beli sesuai dengan apa yang diharapkan, sesuaimdengan apa yang telah di promosikan dan terbukti kebenarannya (Renata dan Prabawani, 2017).

Kepuasan konsumen ditentukan setelah adanya proses pembelian produk. Dalam proses pembelian melibatkan pengambilan keputusan Cara yang signifikan untuk mempengaruhi keputusan pembelian adalah dengan mengaplikasikan strategi pemasaran, karena pada dasarnya terdapat konsep pemasaran taktis dan terkendali yang dilaksanakan secara terpadu untuk mendapatkan respon positif dari para konsumen. Konsumen dan juga pemilik ingin mengidentifikasi berbagai strategi pemasaran yang melatarbelakangi mengapa konsumen berperilaku atau memutuskan untuk berkunjung dan membeli produk dari perusahaan trsebut. Hal ini untuk meningkatkan volume penjualan dan keuntungan.

Permasalahan yang timbul pada keputusan pembelian di Gerai Transmart Carrefour Pabelan di pengaruhi oleh tiga faktor yaitu lokasi, promosi, dan kualitas pelayanan. Dari segi lokasi Transmart Carrefour Pabelan merupakan ritel yang berada di sentral kota sehingga mudah dijangkau. Dari segi promosi Transmart Carrefour Pabelan mengaplikasikan beberapa strategi pemasaran seperti adanya potongan harga (discount), serta gimmick berupa pemberian merchandise dan hadiah lain. Dari segi kualitas pelayanan Transmart Carrefour Pabelan mengaplikasikan quality management yang berbasis customer oriented sehingga Transmar Carrefour Pabelan mampu memberikan pelayanan yang sangat memadai seperti kesopan santunan karyawan kepada konsumen,

Atas dasar latar belakang diatas maka perumusan masalahnya 1. Apakah lokasi berpengaruh signifikan terhadap keputusan pembelian pada gerai transmart Carrefour Pabelan? 2. Apkah promosi berpengaruh signifikan terhadap keputusan pembelian pada gerai transmart Carrefour Pabelan? 3. Apakah kualitas pelayanan berpengaruh signifikan terhadap keputusan pembelian pada gerai transmart Carrefour Pabelan? 4. Apakah lokasi, promosi, dan kualitas pelayananp berpengaruh secara simultan terhadap keputusan pembelian pada gerai transmart Carrefour Pabelan?

\section{LANDASAN TEORI}

\section{Keputusan Pembelian}

Keputusan pembelian merupakan tindakan konsumenuntuk memutuskan pembelian produk atau jasa. Keputusan pembelian dipengaruhi beberapa faktor seperti lokasi, promosi, serta kualitas pelayanan Kotler (2002). Menurut Philip Kotler (2003:202) perilaku keputusan pembelian konsumen dipengaruhi oleh beberapa faktor, diantaranya faktor budaya, sosial, pribadi dan psikologis. 


\section{Lokasi}

Lokasi merupakan suatu area yang membuat produk tersedia bagi pelanggan sasaran. Menurut Ghanimata (2012: 3), lokasi adalah letak toko atau pengecer pada daerah yang strategis sehingga dapat memaksimumkan laba. Pemilihan lokasi usaha yang tepat akan menentukan keberhasilan usaha tersebut dimasa yang akan datang. Adapun faktor-faktor yang harus dipertimbangkan dalam menentukan suatu lokasi usaha bisnis yang akan dilakukan yaitu akses, visibilitas, tempat parkir yang luas, ekspansi.

\section{Promosi}

Menurut (Listyorini, et al, 2012) promosi adalah proses komunikasi suatu perusahaan dengan pihak-pihak yang berkepentingan seperti konsumen. Promosi merupakan salah satu variable dalam strategi pemasaran, kegiatan promosi bukan saja berfungsi sebagai alat untuk mempengaruhi konsumen dalam kegiatan pembelian atau pengguna jasa sesuai dengan keinginan dan kebutuhannya. Tujuan promosi yaitu modifikasi tingkah laku memberi informasi membujuk dan mengingatkan kembali.

\section{Kualitas pelayanan}

Menurut (Tjiptono, 2001) kualitas merupakan suatu kondisi dinamis yang berpengaruh dengan produk jasa manusia proses serta lingkungan yang sangat memenuhi atau melebihi harapan. Ukuran kualitas pelayanan dapat diterapkan pada jasa, tapi sebagian besar ukuran tersebut dikembangkan berdasarkan pengalaman dan penelitian terhadap manufaktur. berikut beberapa ukuran kualitas pelayanan meliputi kendalan, Daya tanggap, jaminan, pehatian, bukti langsung.

\section{METODEXPENELITIAN}

Penelitian ini menggunakan metode kuantitatif. Penelitian ini dilakukan pada konsumen Gerai Transmart Carrefour Pabelan, dilakukan selama 5 bulan, yaitu dari bulanJanuari 2019 sampai Mei 2019. Populasi dari penelitian ini adalah konsumen Gerai Transmart Carrefour Pabelan dengan jumlah 100 responden. Teknik sampling menggunakan random sampling. Sampel penelitian ini berjumlah 100 responden. Analisis data menggunakan uji asumsi klasik dan uji regresi linear berganda.

\section{ANALISIS DATA DAN PEMBAHASAN}

\section{Uji Asumsi Klasik}

1) Uji Normalitas

Digunakan untuk menguji apakah dalam model regresi, variabel pengganggu atau residual memiliki distribusi normal. Hasil Hasil pengujian Kolmogrov-Smirnov menunjukan bahwa nilai Asynp. Sig. (2-tailed) 0,577 lebih besar dari 0,05. Hal ini menunjukan bahwa persamaan regresi untuk model dalam penelitian ini memiliki sebaran data yang normal. 
2) Uji Multikolinearitas

bertujuan untuk menguji apakah dalam model regresi ditemukan adanya kolerasi antar variabel bebas hasil uji multikolinearitas dapat dilihat pada tabel dibawah ini

\begin{tabular}{|l|l|c|l|}
\hline Variabel & Tolerance & VIF & \multicolumn{1}{c|}{ Ket } \\
\hline Lokasi & 0,648 & 1,542 & $\begin{array}{l}\text { Tidak Terjadi } \\
\text { Multikolinearitas }\end{array}$ \\
\hline Promosi & 0,473 & 2,114 & $\begin{array}{l}\text { Tidak Terjadi } \\
\text { Multikolinearitas }\end{array}$ \\
\hline $\begin{array}{l}\text { Kualitas } \\
\text { Pelayanan }\end{array}$ & 0,498 & 2,008 & $\begin{array}{l}\text { Tidak Terjadi } \\
\text { Multikolinearitas }\end{array}$ \\
\hline
\end{tabular}

Dari tabel diatas diketahui bahwa variabel lokasi, promosi dan kualitas pembelian mempunyai nilai tolerance lebih besar dari 0,10 dan nilai VIF kurang dari 10. Maka ketiga variabel tersebut tidak terjadi multikolinearitas.

3) Uji Heterokedastisitas

Uji heteroskedastisitas untuk menguji apakah dalam sebuah model regresi terjadi ketidaksamaan varians dari residual suatu penelitian yang lain. Uji heteroskedastisitas dilakukan dengan uji Glejser, apabila $\mathrm{p}_{\text {value }}>0,05$ maka tidak terjadi heteroskedastisitas hasil pengujian heteroskedastisitas dapat dilihat pada tabel dibawah ini

\begin{tabular}{|l|c|l|l|}
\hline Variabel & $(\mathrm{sig})$ & Batas & \multicolumn{1}{c|}{ Ket } \\
\hline Lokasi & 0,358 & $\begin{array}{l}> \\
0,05 .\end{array}$ & $\begin{array}{l}\text { Tidak Terjadi } \\
\text { Heterokedastisitas }\end{array}$ \\
\hline Promosi & 0,871 & $\begin{array}{l}> \\
0,05 .\end{array}$ & $\begin{array}{l}\text { Tidak Terjadi } \\
\text { Heterokedastisitas }\end{array}$ \\
\hline $\begin{array}{l}\text { Kualitas } \\
\text { Pelayanan }\end{array}$ & 0,239 & $>$ & Tidak Terjadi \\
& & $0,05$. & Heterokedastisitas \\
\hline
\end{tabular}

Dari tabel diatas diketahui bahwa variabel lokasi, promosi dan kualitas pelayanan mempunyai nilai sign $\geq 0,05$. Maka ketiga variabel tersebut tidak terjadi heterokedastisitas.

\section{Uji Regresi Linear Berganda}

digunakan untuk mengetahui seberapa besar pengaruh lokasi, promosi dan kualitas pelayanan terhadap keputusan pembelian pada Gerai Transmart Carrefour Pabelan. Hasil regresinya seperti pada tabel dibawah ini :

Tabel 1 : Hasil Uji Regresi Linear Berganda

\begin{tabular}{|l|c|c|r|r|c|}
\hline \multicolumn{1}{|c|}{ Variabel } & \multicolumn{1}{c|}{$\mathrm{B}$} & \multicolumn{1}{c|}{ beta } & $\mathrm{t}_{\text {hitung }}$ & \multicolumn{1}{c|}{ Sig t } & Ket \\
\hline \multicolumn{1}{|c|}{$($ Constant $)$} & 3,504 & & & & \\
\hline Lokasi & 0,204 & 0,233 & 2,859 & 0,005 & Signifikan \\
\hline Promosi & 0,421 & 0,452 & 4,746 & 0,000 & Signifikan \\
\hline
\end{tabular}




\begin{tabular}{|l|c|l|l|l|l|}
\hline Kualitas Pelayanan & 0,198 & 0,199 & 2,142 & 0,035 & Signifikan \\
\hline F hitung & 45,671 & & & & \\
\hline Sig F & 0.000 & & & & \\
\hline R square & 0,575 & & & & \\
\hline \multicolumn{2}{|l|}{ Variabel Dependent } & : Keputusan Pembelian & \\
\hline
\end{tabular}

Dari tabel diatas didapatkan persamaan regresi sebagai berikut :

$\mathrm{Y}=3,504+0,204 \mathrm{X}_{1}+0.421 \mathrm{X}_{2}+0,198 \mathrm{X}_{3}+\mathrm{e}$

Keterangan :

a. Nilai Konstanta sebesar 3,504 artinya apabila variabel independen yaitu lokasi, promosi,dan kualitas pelayanan nilainya 0 , maka variable keputusan pembelian akan berada pada angka 3,504.

b. Koefisien variabel lokasi dari perhitungan regresi linier berganda nilai coefficients 0,204. Hal ini berarti jika lokasi menigkat, sementara nilai koefisien variabel promosi dan kualitas pelayanan tetap, maka nilai keputusan pembelian akan meningkat dengan perbandingan $1: 0,204$.

c. Koefisien variabel promosi dari perhitungan regresi linier berganda nilai coefficients 0,421 . Hal ini berarti jika promosi menngkat, sementara nilai lokasi dan kualitas pelayanan tetap, maka nilai keputusan pembelian meningkat dengan perbandingan $1: 0,421$.

d. Koefisien variabel kualitas pelayanan dari perhitungan regresi linier berganda nilai coefficients 0,198. Hal ini berarti jika kualitas pelayanan meningkat, sementara nilai lokasi dan promosi tetap, maka nilai keputusan pembelian meningkat dengan perbandingan $1: 0,198$.

\section{Uji Hipotesa}

1. Uji F

Analisis ini digunakan untuk mengetahui signifikasi pengaruh variabel lokasi, promosi dan kualitas pelayanan secara simultan terhadap keputusan pembelian. Hasil pengujian didapatkan hasil nilai $\mathrm{F}$ hitung sebesar 45,671 dan signifikan 0,000 yang berarti secara simultan vaiabel lokasi, promosi dan kualitas pelayanan berpengaruh terhdap keptusan pembelian .

2. Uji t

Digunakan untuk menguji signifikasi secara parsial pengaruh variabel independen yaitu lokasi, promosi, dan kualitas pelayanan terhadap variabel dependen yaitu keputusan pembelian. Berdasarkan analisis pada tabel 1 dapat disimpulakan sebagai berikut :

a. Pada Variabel Lokasi nilai t hitung $(2,859) \geq \mathrm{t}$ tabel (1984) dengan signifikan $0,005 \leq 0,05$ dapat disimpulkan lokasi berpengaruh positiif dan signifikan terhadap keputusan pembelian pada gerai transmart carrefour pabelan. 
b. Pada Variabel Promosi nilai thitung $(4,746) \geq \mathrm{t}$ tabel (1984) dengan signifikan $0,000 \leq 0,05$ dapat disimpulkan promosi berpengaruh positif dan signifikan terhadap keputusan pembelian pada gerai transmart carrefour pabelan.

c. Pada Variabel kualitas pelayanan nilai t hitung $(2,142) \geq \mathrm{t}$ tabel (1984) dengan signifikan $0,035 \leq 0,05$ dapat disimpulkan kualitas pelayanan berpengaruh positif dan signifikan terhadap keputusan pembelian pada gerai transmart carrefour pabelan.

\section{Koefisien Determinasi}

Hasil dari perhitungan regresi dapat diketahui bahwa koefisien determinasi (adjusted R2) yang diperoleh sebesar 0,575. Hal ini berarti 57,5\% variasi variabel keputusan pembelian dapat dijelaskan oleh variabel lokasi, promosi, dan kualitas pelayanan, sedangkan sisanya $42,5 \%$ adalah variabel lain dari luar penelitian.

\section{Pembahasan}

1) Hasil analisis uji $t$ menunjukkan lokasi berpengaruh positif dan signifikan terhadap keputusan pembelian pada Gerai Transmart Carrefour Pabelan. apabila ketersediaan lahan parkir, lokasi yang aman dan nyaman serta lokasi yang strategis berpengaruh terhadap keputusan pembelian pada Gerai Transmart Carrefour Pabelan. Hasil penelitian ini sejalan dengan penelitian sebelumnya yang dilakukan oleh Putra (2014) dan Walukow (2014).

2) Hasil analisis uji $t$ menunjukkan promosi berpengaruh positif dan signifikan terhadap keputusan pembelian pada Gerai Transmart Carrefour Pabelan. karena dengan adanya promosi bertujuan untuk menjalin komunikasi dengan konsumen secara langsung maupun tidak langsung, serta memberikan informasi mengenai produk produk apa saja yang terdapat pada Gerai Transmart Carrefour Pabelan. Salah satunya dengan memberikan promosi potongan harga, buy 1 get 1 atau berupa tawaran menarik dengan mengadakan ivent - ivent kecil. Hasil penelitian ini sejalan dengan penelitian dari Sundalangi (2013), Putra (2014) dan Walukow (2014).

3) Hasil analisis uji $t$ menunjukkan kualitas pelayanan berpengaruh positif dan signifikan terhadap keputusan pembelian pada Gerai Transmart Carrefour Pabelan. Hasil penelitian ini sejalan dengan penelitian dari Putra (2014). Kualitas pelayanan dapat berpengaruh terhadap keputusan pembelian pada Gerai Transmart Carrefour Pabelan karena dengan kualitas pelayanan yang baik dan daya tanggap karyawan setiap departemen terhadap apa saja yang ada di Gerai Transmart Carrefour Pabelan akan menambah daya tarik tersenderi untuk konsumen yang sedang berkunjung, karena konsumen merasa cepat dan tepat untuk mendapatkan apa yang sedang mereka inginkan dan mereka butuhkan ketika berkunjung pada Gerai Transmart Carrefour Pabelan.

\section{KESIMPULANt}

Berdasarkan hasil penelitian dapat diambil kesimpulan Lokasi, promosi dan kualitas pelayanan secara simultan dan signifikan berpengaruh terhadap keputusan pembelian pada Gerai Transmart Carrefour Pabelan. Sedangkan secara parsial 
variabel Lokasi, promosi dan kualitas pelayanan berpengaruh positif dan signifikan terhadap keputusan pembelian pada Gerai Transmart Carrefour Pabelan.

\section{SARAN}

1) Lokasi Gerai Transmart Carrefour Pabelan sebaiknya lebih diperhatikan lagi seperti lahan parkir yang luas, aman dan nyaman. Tidak kalah pentingnya lagi toilet, dengan memberikan toilet pada setiap lantai untuk memudahkan konsumen mencarinya.

2) Promosi melalui media offline maupun online lebih ditingkatkan dengan selalu update apa saja promosi yang sedang ditawarkan Gerai Transmart Carrefour Pabelan supaya konsumen baru atau konsumen yang berlangganan mengetahuinya. Promosi potongan harga, buy 1 get 1 atau promosi menarik lainnya harus sering diberikan supaya konsumen tertarik dan berkunjung kembali ke Gerai Transmart Carrefour Pabelan.

3) Pada kualitas pelayanan salah satunya dengan memberikan pelayanan terbaik selalu ramah, sopan dan santun kepada konsumen yang sedang berkunjung. Setiap karyawan harus menguasai serta tanggap dengan promosi yang sedang berlangsung atau produk - produk apa saja yang disediakan oleh Gerai Transmart Carrefour Pabelan supaya konsumen lebih nyaman berinterkasi dengan karyawan.

\section{DAFTAR PUSTAKA}

Brata, B. H., Husani, S., \& Ali, H. (2017). The Influence of Quality Products, Price, Promotion, and Location to Product Purchase Decision on Nitchi At PT. Jaya Swarasa Agung in Central Jakarta . Saudi Journal of Business and Management Studies. Universitas Jakarta. II, 433-445

Heryanto, I. (2015). Analisis Pengaruh Produk, Harga, Distribusi, Dan Promosi Terhadap Keputusan Pembelian Serta Implikasinya Pada Kepuasan Pelanggan. Jurnal Ekonomi, Bisnis dan Entrepreneurship. STIE Pasunandan Bandung. IX (2), 80-101

Pawenang, S., \& Kustiyah, E. (2011). Pengantar Ekonometrika. Idea Press. Yogyakarta. Skripsi. Universitas Islam Batik Surakarta

Renata, T. R., \& Prabawani, W. (2018). Pengaruh Harga, Promosi Penjualan Dan Kualitas Pelayanan Terhadap Minat Bermain Ulang Di Trans Studio Mini Setia Budi Semarang Melalui Kepuasan Pengunjung Sebagai Variabel Intervening (Studi Kasus Pada Pengunjung Trans Studio Mini Setia Budi Semarang di Kota Semarang Dan Sekitarnya). Jurnal Ilmu Administrasi Bisnis. Universitas Diponegoro. VII (3)

Yola, M., \& Budianto, D. (2013). Analisis Kepuasan Konsumen Terhadap Kualitas Pelayanan Dan Harga Produk Pada Supermarket Dengan Menggunakan Metode Importance Performance Analysis (IPA). Jurnal Optimasi Sistem Industri. Universitas Islam Negeri Sultan Syarif Kasim Riau. XII (12), 301-309 